\title{
Drivers of E-Business Diffusion in Tourism: A Decision Tree Approach
}

\author{
Biljana Rondović1 ${ }^{1}$ Tamara Djuričković ${ }^{2}$ and Ljiljana Kašćelan ${ }^{3}$ \\ 1 University of Montenegro, Faculty of Economics, Podgorica, Montenegro, biljaro@ac.me \\ ${ }^{2}$ Agency for Control and Quality Assurance of Higher Education, Podgorica, Montenegro, \\ tamara.djurickovic@akvo.gov.me \\ 3 University of Montenegro, Faculty of Economics, Podgorica, Montenegro, ljiljak@ac.me \\ Received 17 November 2017; received in revised form 12 February 2018; accepted 28 February 2018
}

\begin{abstract}
The aim of this paper is to examine the individual and interactive influence of organizational, technical and environmental factors on the diffusion of e-business in Montenegrin tourism organizations. In accordance with this goal a decision tree method is used in this paper. The results showed that organizational factors have the highest individual impact on e-business diffusion and that there is a strong interactive influence of organizational, information technology integration and external support factors. The obtained results provide important information for management and decision-making in conditions when diffusion of information technology innovation needs to be accelerated in such a way that instead of influencing only one group of factors, it affects several factors simultaneously which, in interaction with one another, lead to a greater degree of e-business diffusion.
\end{abstract}

Keywords: Information and communication technology diffusion, E-business diffusion, Decision tree, Management, Technology-Organisation-Environment (TOE) framework 


\section{Introduction}

In transition countries, tourism has long been recognized as an important catalyst for social and economic development. Studies dealing with the analysis of the impact of tourism on investment growth, increasing employment, the growth of tax revenues and strengthening the cultural identity of a country [17], [34], [79] should be supplemented by those offering new concepts, ideas and practices for the survival of companies in the digital economy. In the conditions imposed by the digital economy, it has been recognized that the use of ICT in providing tourist services is a key factor for the success of tourism enterprises, but also that ways and means should be sought to make this process faster and more effective [58]. In accordance with this need, but also with the fact that tourism is an information-oriented industry and, as such, suited to the advantages offered by ICT [23], it is necessary to examine the factors affecting the degree of e-business use.

In the professional literature, this area is studied within the context of innovation and technology diffusion theory [71]. On the basis of this theory, numerous studies have been undertaken to examine the factors that influence the adoption of e-businesses in tourism enterprises, and these are undoubtedly useful because they contribute to a better understanding of the factors on which the potential for adoption relies [2], [83]-[84]. Since the TechnologyOrganization-Environment Framework - TOE [20] has often been used to examine factors that influence the adoption of new technologies, it was logical to expand the use of this framework to e-business [60], [62]. However, the authors note that there is limited empirical evidence of how technical, organizational and environmental factors influence the use of e-business in this industry (after adoption), and believe it would be useful to fill this gap in the existing literature, all the more so since some authors have drawn attention to the importance of distinguishing between the adoption and the degree of use of ICT, [85], of which e-business is an integral part.

In previous studies [42], [44], the factors that influence e-business difusion have been examined predominantly using traditional statistical methods. Most of these methods (such as the Structural Equation Modeling - SEM and the Partial Least Squares Path Modeling - PLSPM) have their own inbuilt model assumptions and pre-defined underlying relationships between dependent and independent variables. If these assumptions are violated, the model might then provide erroneous estimations. The decision tree (DT) method does not require a pre-defined underlying relationship. In addition, the method allows a great many explanatory variables to be processed and the most important variables are easy to find. Another advantage of the DT analysis is that it does not need to specify a functional form and the problem of multicollinearity of input variables is thus avoided. Moreover, the method allows for the detection of the interactive effects of factors and it is both practical and easy for management to interpret, since the system consists of a set of efficient if-then rules [19].

For this reason, the purpose of this study is to examine whether or not the DT method can efficiently identify the key factors that affect e-business diffusion. The second goal is to consider the differences in the influence of the factors depending on the type of e-business a company engages in (be that business-to-business (B2B) or business-toconsumer (B2C)). Finally, the study should provide appropriate recommendations both for managers in tourism companies and for policy makers in the field of ICT, in such a way that they will be able to identify barriers to the development of electronic business and thus this paper will raise awareness of the benefits e-business brings both in national and international contexts.

The study uses data collected via a survey conducted in Montenegrin tourist companies in 2015. Such a study may prove useful for tourism enterprises, especially in economies such as Montenegro's, which do not have a long tradition in the use of sophisticated technologies, or else which cannot boast long practice in terms of the informatization of business processes. The obtained results can be used in a generalized context and may help in breaking down these barriers.

The rest of the paper is organized as follows: the second part offers an overview of the literature on the topic and gives a critical review of the research conducted so far, in which the authors found their motive for the present study; the third part features the research methodology i.e. the research questions of the survey and the characteristics of the sample as well as the applied DT method; the fourth section presents the results with discussion. The last section offers concluding remarks, study limitations and guidelines for future research.

\section{Literature Review}

Not wanting to underestimate the importance of studies dealing with the reasons for [6], [82], consequences of [11], [41] and ways of using internet technologies in tourism companies [5], [22], for the needs of the present study, the authors focused on two important areas of theoretical research: e-business diffusion (viewed in the context of the Innovation Diffusion Theory), and e-business assimilation (observed in the context of the theory of assimilation of innovation), as well as on the literature based on the theoretical frameworks from which the factors influencing ebusiness diffusion can be identified, in particular in tourism companies from Montenegro. 
Numerous papers on ICT are based on the Innovation Diffusion Theory developed by Rogers [71], where the diffusion of technological innovations is defined as the process of expanding the use of new methods, processes and technologies within an enterprise. Given that e-business is recognized as a technological innovation that affects business processes and transforms them in some way [48], [50], this theory has found a strong foothold in studies dealing with the adoption and diffusion of e-business.

From a review of the literature, it can be concluded that scholars have so far mainly focused on e-business adoption [37], [59]-[60], [88]. Since successful adoption does not necessarily lead to extensive usage [14], [85], and since the same factors may have a different significance in different phases of e-business assimilation [47], [87], the authors have accepted the suggestion that IT innovations should be considered alongside the assimilation of innovations [25]

The assimilation of innovation can be seen as the degree to which innovation is accepted, expanded and entered into routine use [85]. Thanks to this interpretation of the concept, it is possible to comprehensively study all the activities from the phase of the initiation of the introduction of the system to the phase that follows the implementation of the system. Close to this interpretation but the context of radio-frequency identification (RFID) technologies, Hardgrave et al. [32], introduce the notion of the assimilation hierarchy and in that way distinguish between different hierarchical levels. At the basic level, the technology is first introduced, which is followed by a degree of understanding of the technology, and only at the third level does the technology begin to create business values. Based on this idea, and intending to explore how the telehealth innovation transition process occurs, Cho et al. [16] recognize four stages in the process- adoption, implementation, commercialization and diffusion. In their research in the field of automated office business, Swanson and Ramiller [78], also recognize four levels of the assimilation of innovation: comprehension, adoption, implementation, and assimilation.

Meyer and Goes [56], suggest a five-phase approach: knowledge awareness, evaluation, adoption, implementation, and expansion. Besed on Kwon and Zmud's [40] six-phase model, Rajagopal [68] examines the importance of factors in the implementation of the enterprise resource planning (ERP) system in the following phases: initiation, adoption, adaptation, acceptance, routinization and infusion.

By examining the findings of the above mentioned studies, it becomes obvious that the authors agree that the diffusion process involves a different degree of the use of technology and that observing the problem from that angle can lead to a comprehensive insight into the challenges that the implementation of IT innovation brings. However, there is no concensus on how to define the degrees of IT innovation diffusion.

By studying the available literature on e-business adoption and use in tourism enterprises, it can be seen that the authors have so far mostly dealt with the problem of e-business adoption [2], [83]-[84]. These studies are undoubtedly useful, but the body of research on this subject would definitely be richer if it were complemented by research that focuses on the period after e-business adoption. Bearing in mind this fact and the recommendations that a larger research basis for companies which have already adopted e-business should be created [25], [87], for the purposes of this study, the authors considered only those companies that had already adopted the concept of ebusiness. The authors believe that a more complete picture of the expansion of this type of technological innovation can only be obtained by examining the factors that individually and in interaction with one another influence ebusiness diffusion in the post-adoption phase. Since the pilot survey showed that employees working for Montenegrin tourism companies do not differentiate between the phases of technology use (after its adoption), the degree of e-business diffusion is measured by the perception of the level of use of e-business applications (in a range from very low to very high).

By studying the theoretical frameworks used in other studies conducted so far, it can clearly be noted that they differ depending on whether a study examines the organizational adoption and use of e-business or it deals with its adoption and use by individuals, i.e., employees or consumers. As the focus of this paper is on the organizational expansion of e-business as an ICT innovation, studies employing empirically-grounded theories concerning the organizational adoption and expansion of ICT innovation were used as the theoretical basis.

In terms of the organizational adoption and diffusion of ICT innovation, an integral part of which is e-business, in the scholarly literature in this field it has been shown that any analysis of the impact of technological, organizational and environmental factors, that is, a TOE Framework analysis [20], can lead to significant results [3], [60], [62]. Considering that this framework has proved to be a good choice in studies on e-business adoption in tourism enterprises [66], [83]-[84], the authors decided to conduct this research using the TOE framework.

It was thanks to many studies that three groups of factors were identified on which the degree of adoption of ebusiness in the tourism sector still depends - technical, organizational and environmental factors. Some studies focused on the analysis of the impact of one group of factors only on e-business diffusion. For example, Mun [57] examines the different stages of e-business diffusion in enterprises and places an emphasis on technical factors, while other researchers limit their studies to organizational [72], [75], or environmental factors [24], [77] only. Nevertheless, there are a greater number of studies which simultaneously observe all three sets of factors. In contrast to Oliveira and Martins [60] who compared intersectoral differences in terms of e-business adoption in EU27 companies showing that in all tourism companies, there is almost an equal statistically significant impact of all three sets of factors, other studies have shown that there are significant differences in terms of the degree of impact of 
these factors [2], [64]. Also, the literature shows that there is no doubt among scholars as to the fact that a company's size dictates the manner and extent of the implementation of e-business in tourism companies [10], [31] and it is clear that larger companies have fewer problems in this regard, because they are financially more stable, technically better-equipped and less dependent on environmental factors. Therefore, scholars face another problem, and that is to find the answer to the question as to why there are different findings for small companies even though they belong to the same industry? The survey conducted for Austrian tourism enterprises [26] showed that there are differences in terms of the impact of this group of factors depending on which online platform a tourist company uses. The degree of impact of these factors also varies depending on whether a company conducts its business relying on the B2B or B2C concept [42], [51], but also on the extent of its use of e-business applications [66]. Ranking the level of the individual impact of these three groups of factors on a sample of small enterprises in the field of tourism, [84] provides evidence that in developing countries environmental factors exert the greatest influence. Similar findings occurred in research conducted in the Maldives [4].These studies prove that any delay arising from the institutional framework and concerning the execution of strategic plans in the field of ICT policy interferes with the adoption and diffusion of e-business in tourism enterprises. On the other hand, other studies, also conducted in underdeveloped market economies, show that the greatest impact is exerted by either organizational [2], [64], or technical factors [27] It is this heterogeneity of findings that prompted the authors to conduct an analysis where not only the individual, but also the interactive impact of the observed factors is explored. This was especially so given that no research conducted so far has shown whether the impact of a certain factor is equally strong when viewed individually and when viewed in interaction with other factors.

In terms of the methodological aspect, in many of the above-mentioned studies, a standard two-stage approach was used. First, the reliability and validity of the measures were statistically determined (factor analysis). In this step, a set of independent variables is determined that are important for the estimation of the dependent variable. In the second step, the structural relationships between the latent constructors are tested via regression. The structural model reflects the implied linear causal relationships between the dependent variable and the independent variables defined by the initial hypotheses. By testing the structural model, the significance and influence of a particular independent variable on the dependent variable is determined, i.e., the hypotheses about this influence are tested. If any of the assumptions is omitted, the model can lead to incorrect results. Applying a two-stage approach, Vladimirov [83] found the R-square of about 60\%, while Palacios-Marqués, Soto-Acosta \& Merigó [62] reported about $50 \%$ (which means that the selected factors determine the target variable to this degree).

Using the DT method we are able to automatically find those independent variables that best predict the target variable. To be specific, the method does not require pre-defined hypotheses as to the relationship between the target variable and the predictor (independent) variables and can provide insight into additional conditional relations, which might not have been included in the set hypotheses [19]. Using the DT method for the detection of key factors related to the quality of transport, J. de Ona, R. de Ona \& Calvo [19] achieved an accuracy of their model of about $60 \%$ and showed that this approach can be successfully used to assess the significance of input variables and their impact on dependent variables.

\section{Research Methodology}

In this section, the authors have provided information about research questions, conceptual model as well as information about the reasons for chosing the variables and items. Also, the authors have described how they collected data and explaned the DT method which is used to analyse those data and to generate a model.

\subsection{Study Questions and Selection Criteria}

According to the defined research aim, the authors have identified two research questions:

1. What are the determinants of e-business diffusion and what is their individual and interactive impact on enterprises in the tourism sector?

2. Are there differences in the factors that influence the degree of e-business diffusion between $\mathrm{B} 2 \mathrm{C}$ and $\mathrm{B} 2 \mathrm{~B}$ companies in tourism, and if so, what are they?

E-business has emerged thanks to ICT innovation (primarily, thanks to the Internet). This type of business requires a certain organizational structure and specific organizational adjustments and is often shaped by external demands and pressures. All these aspects are covered by the TOE framework. [20]. However, since, when studying technical innovations and when a theoretical framework is to be chosen and its determinants defined, the characteristics of the studied technology must be taken into account [12], [30] as well as the results of the studies on ICT diffusion conducted so far [1], [37], [55], [69], [76], the authors defined the conceptual model shown in Figure 1. 


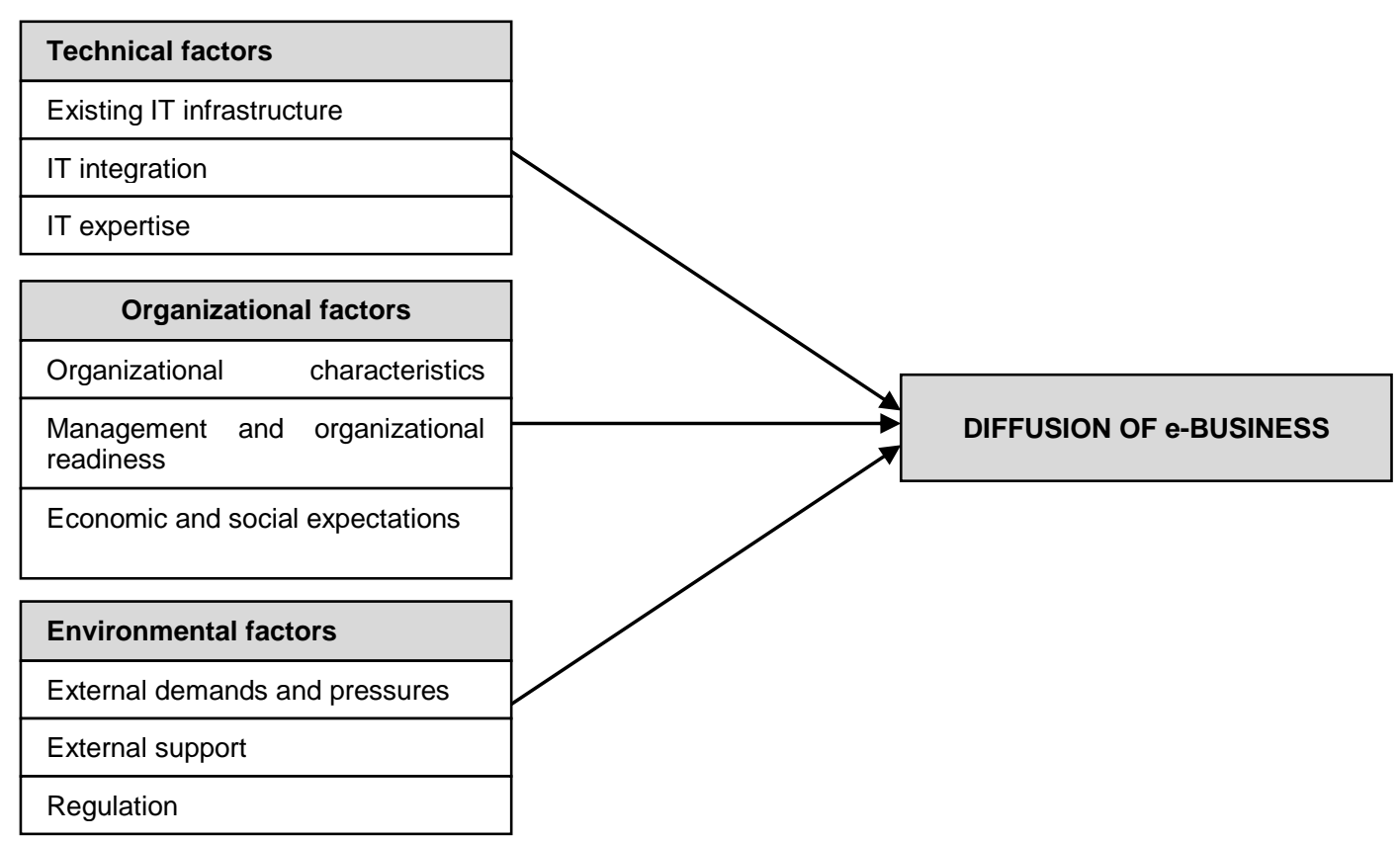

Figure 1: The proposed research framework

The proposed model incorporates three important dimensions of e-business diffusion: technological, organizational and environmental context (as shown on the left side of Figure 1).

The technological context encompasses both the internal and external technologies necessary for a company's operation [61], [86] claiming, for example, that companies cannot count on online transactions if they are unable to provide the necessary technologies and preconditions for the training of employees and for internal and interagency integration.

For this reason, the authors proposed three groups of technological factors that were found in the existing literature as significant for the diffusion of ICT innovation: IT infrastructure, IT expertise and IT integration. The necessary IT infrastructure, IT expertise and IT integration are often referred to jointly as technological readiness [1], [52], [69]. In terms of the startup, adoption and further implementation of the concept of e-business, companies with a higher level of technological readiness are in a better position [21], [87].

E-business adoption and diffusion depends on a reliable and high quality IT infrastructure [48] and when an adequate IT platform is provided in the initial phases of e-business assimilation, concerns about these factors may be reduced during more advanced phases of e-business implementation [26], [70], [85]. In addition to a reliable IT platform on which to build their e-business, IT expertise is measured by the ability of staff to contribute via their own knowledge to the development and use of quality information systems [48]-[49]. Companies that have IT specialists adopt e-business more quickly [49] and create the preconditions for the efficient use of e-business [36]. The ability of a company to recognize the importance of this factor and invest in strengthening IT expertise affects the entire ebusiness implementation process [49], [70].

IT integration is defined as a measure of the compatibility of an information system with the existing business processes and existing information systems, but also a measure of the compatibility of the internal systems with those of their business partners [87]. The existing literature provides evidence that technology integration is an essential prerequisite for the use of e-business [35], as well as that the failure to implement this concept tends to occur due to the issue of non-integration among backend technologies [45]. Chan and Chong [13] emphasize that the flow of information is not possible unless there is compatibility between an e-business platform and the existing internal and external information systems. Companies with a higher degree of IT integration have a greater chance of providing the right conditions for using e-business in terms of both breadth and depth [85].

The organizational context refers to the characteristics and resources of an enterprise, including the company's size, the degree of centralization, the degree of formalization, the company's managerial structure and human resources, the amount of necessary resources and the connections between employees [46]. Alone or together with other determinants, the organizational characteristics of an enterprise (size, age, business mission and vision) are commonly used in studies on ICT adoption and diffusion [37], [76]. In addition to these organizational characteristics, the ability to adopt and the quality use of technology depends on the management's attitude to the issue [37], [53], the characteristics of the management [81] and their financial and moral support [63] , but also on the extent to which they can encourage further use of new technologies [55]. A great number of studies show expected benefits to be an important factor in the adoption of innovation. It has been observed that they influence: the adoption of mobile supply 
chain management [13], decision-making to invest in RFID system [15], [46], the intention to adopt SaaS technology [55], the initiation and the early stages of acceptance of e-business [29], the adoption of CRM and so on. For this reason, for the purposes of this study, three factors feature within the organizational context in the proposed model: the organizational characteristics of the company, management and organizational readiness and the expected benefits. And finally, depending on the nature of the IT innovation, environmental factors may include: the size and structure of the industry, competitors, regulatory environment, macroeconomic context and other issues.

Companies often initiate and adopt new technologies due to the formal and informal demands, expectations and pressures of business partners or subcontractors, the media, or other stakeholders. In practice, they can dictate the degree of the use of ICT [33], [74]. As is claimed by Jeyaraj, Rottman \& Lacity [38], competition is a particularly important factor for the adoption of IT innovation. It is all the more so, because companies adopt and use IT innovation due to competitive incentives and pressures, which, in turn, thanks to feedback effects, dictate the degree of use of IT innovation by their competitors [28].

Incentives and forced pressures can be expected from regulatory bodies, dominant organizations and parent corporations [80]. In studies, particularly those conducted in developing countries, it is observed that the regulatory environment affects the degree of use of the concept of e-business [86]. Taking into account the nature of ebusiness as an IT innovation, the results of previous studies, and the nature of the tourism sector, the authors defined three determinants of e-business diffusion within the environmental context: external demands and pressures, external support and legal regulation.

Taking into account the nature of e-business (as an IT innovation), the economic activity that was observed in this study and the reference literature that supports the unbalanced number of items to measure the selected variables [29], [48], [86], [89] a list of variables and items has been defined, which is provided in Appendix B.

Finally, in order to evaluate the degree of e-business diffusion, the authors asked the respondents to rate the degree of the use of e-business applications in a range from $1=$ very low to $7=$ very high, which is close to what was presented in [73].

The Survey - in order to obtain answers to the research questions, a survey was developed for tourism enterprises from Montenegro which have accepted the concept of e-business and have their own web site. In order to empirically test the research model, a list of 150 companies was obtained from the Central Tourist Register of the Ministry of Sustainable Development and Tourism of Montenegro, consisting of travel agencies engaged in mediation and organizing travel, categorized catering facilities and categorized service providers in nautical tourism. Due to the size of the surveyed sample, the authors did not investigate the difference in the diffusion of e-businesses in different groups of tourist companies.

The authors forwarded a formal survey to marketing and IT managers, guided by the idea that they should be well aware of business processes and IT support for these processes, and that they were involved in decision-making processes concerning e-business adoption. The survey was accompanied by a letter in which the authors informed the respondents of the aim of the study and their commitment to protecting the confidentiality of data as well as to the aggregated presentation of the results of the study. In addition, in order to increase the response rate, the authors promised to inform all respondents of the final results of the study (if interested).

The survey lasted 90 days (from September to December 2015). Out of the forwarded 350 surveys (sent to 150 companies), 152 surveys were returned completely filled out (from 76 companies), giving a response rate of $43.4 \%$ for surveys (with a $50.7 \%$ response rate for companies). Incomplete surveys and those obtained from companies that did not adopt the concept of e-business were not considered.

As the authors have already stated, for the purpose of the analysis of the survey results, based on the recognized criteria (factors), nine independent variables were defined, within three contexts. First, technological context contains three variables: IT infrastructure, IT expertise i IT integration. Second, organizational context contains variables: organizational characteristics, management and organizational readiness and economic and social expectations, while third, environmental context contains variables related to external demands and pressures, external support and regulations. Based on the questions in the survey, 29 attributes were assigned to these variables (Appendix B).

The value of the variable was calculated as the average value of the corresponding attribute [8]. The assessment of the current degree of diffusion of e-business in the surveyed companies was taken to be the dependent variable. Table 1 shows the dependent variable, the nine independent variables, the control variable and their distribution. For the assessment of the current degree of the use of the concept of e-business as well as the impact of the defined factors on the diffusion of e-business, a 7-point Likert scale was used [7], [37]. 
Table 1: The variables for analysis generated based on the results of the survey

\begin{tabular}{|l|l|l|l|l|}
\hline Role & Name & Type & Statistics & Range \\
\hline Dependent & Diffusion & numeric & avg $=2.678+/-0.760$ & {$[2.000 ; 4.000]$} \\
\hline Independent & IT.infrastruct & numeric & avg $=6.539+/-0.574$ & {$[5.000 ; 7.000]$} \\
\hline Independent & IT.integration & numeric & avg $=5.062+/-0.476$ & {$[4.000 ; 6.000]$} \\
\hline Independent & IT.expertise & numeric & avg $=6.664+/-0.488$ & {$[5.000 ; 7.000]$} \\
\hline Independent & Org.character & numeric & avg $=5.534+/-0.299$ & {$[4.600 ; 6.200]$} \\
\hline Independent & Org.readiness & numeric & avg $=4.224+/-0.533$ & {$[3.000 ; 5.500]$} \\
\hline Independent & Expectations & numeric & avg $=4.802+/-0.201$ & {$[4.167 ; 5.167]$} \\
\hline Independent & Ext.req & numeric & avg $=5.792+/-0.338$ & {$[5.000 ; 6.333]$} \\
\hline Independent & Ext.support & numeric & avg $=4.414+/-0.517$ & {$[2.500 ; 5.500]$} \\
\hline Independent & Regulation & numeric & avg $=2.368+/-0.484$ & {$[2.000 ; 3.000]$} \\
\hline Control & E business & nominal & $\begin{array}{l}\text { mode }=\text { B2C }(101), \text { least }=\text { B2B } \\
(51)\end{array}$ & B2C $(101)$, B2B (51) \\
\hline
\end{tabular}

\subsection{The Decision Tree Method}

For the analysis of the collected data and generating a model by which the answers to the research questions could be obtained a data mining DT method was used.

This method systematically analyzes data to derive important relationships between the target (dependent) variable and the input (independent) variables and display them in a tree structure. The tree is composed of nodes, branches and leaves. Each node in the tree is associated with one of the input variables and each branch of the tree is associated with a subset of values of the corresponding target variable. If the target variable is discrete (has a limited number of values), then the tree is considered to be a classification tree and each leaf represents one value of the target variable (one class). The DT algorithm also generates relative frequencies for each leaf, i.e., the probability of belonging to the class that this leaf represents.

The process of the induction of the tree recursively distributes the initial set of data into subsets. The goal of each iteration is to obtain the best possible division, i.e., as pure as possible a set in relation to the determined value of the target variable. The method of division may differ depending on the DT algorithm. It defines the variable that will be assigned to a node in a tree and divides a collection of data by the values of the variable into subsets, so that the purity of the obtained subsets is maximized. Each branch of the tree that comes out of that node corresponds to one of the obtained subsets. In this paper, the Classification and Regression Trees (CART) algorithm was used, where the division is based on the theory of information (entropy) and the purity of the set is measured against the distance between probability distributions (Gini Index) [9], [67].The divisions are purely binary and independent variables can be discrete and continuous.

In the process of DT induction, the CART method also generates variable importance. During the distribution, a variable can appear multiple times as the primary (which enters the final DT model) or the surrogate (which does not appear in the DT model). An overall measure of variable importance is the sum of the quality of the split measures for each split for which it was the primary variable, plus the quality for all splits in which it was a surrogate [9], [67]. In the CART output these are scaled to sum to 100 and rounded values are shown, omitting any variable whose proportion is less than $1 \%$.

The DT method can be used for classification. When a classification tree is generated across the entire data set with a categorical target variable, then it is classification. As a result of the classification, the initial data set is divided into classes (which are defined by the values of the target variable) and each class is assigned an appropriate classification rule that is read from the tree going along paths from the root to the leaves. The model thus generated is explanatory because it explains the classes by using appropriate rules. The ratio of the amount of correctly classified data and the total amount of data represents the accuracy of the classification.

In this analysis, the independent variables are the nine factors influencing the diffusion of e-business as defined in section 3.1, while the target variable is the degree of e-business diffusion. In relation to the research questions, the aim is to discover and simply interpret the interactive and individual impact of the nine factors on the degree of ebusiness diffusion. In order to achieve this goal, the classification CART tree method was selected because through this method, classification rules are obtained for the individual values of the target variable, i.e. the degrees of ebusiness diffusion. The rules describe the required interactive impact in a simple way. This method also generates the significance of variables and, therefore, the impact of individual factors can be determined. 


\section{Results and Discussion}

In order to answer the first research question, a classification decision tree was generated based on TOE factors, using the CART method (Figure 2).

By analyzing the decision tree in Figure 2, it can be seen that organizational characteristics is the root variable, which means that this variable has the highest classification power (the highest classification accuracy will be achieved if the breakdown of the starting data set is performed first by this variable and the critical value 5.9). In the starting data set, 76 rows have a degree of e-business diffusion of 2; 49 rows have a degree of e-business diffusion of 3 and 27 rows a degree of e-business diffusion of 4 . From the root variable, the data set branches into the left subtree (for the values of the root valuable lower than 5.9) that relates to the lower degrees of e-business diffusion of 2-3, and the right sub-tree (for the values of the root valuable greater than or equal to 5.9) which is related to greater degrees of e-business diffusion, specifically 4 . The right sub-tree immediately ends in a leaf because very few data have a root value greater than 5.9 (a total of 13). The left sub-tree includes 139 data items out of which 73 have a degree of diffusion of 2; 45 have a degree of diffusion of 3, and for 21 a degree of diffusion that is 4 . In the left subtree, the splitting is continued by attribute and by the critical value, which now has the highest classification power. It continues on until a leaf is reached. For example, a subset of data corresponding to the leaf-Node 5 contains 16 data items with a degree of e-business diffusion of 2; 3 data items with a degree of e-business diffusion of 3 and 0 data items with a degree of e-business diffusion of 4 . This node represents the class of e-business diffusion rated 2 , because it contains the most data with this degree of e-business diffusion.

The ratio of the amount of correctly classified data and the total amount of data represents the accuracy of the classification. By collecting the correctly classified data by sheets $(16+20+15+10+11+8+5+6)$ we obtain the number 91 , which is $59.87 \%$ in relation to the total number of data of 152 . Therefore, the overall accuracy of the classification in this model is $59.87 \%$ (Additional performance data for the model are presented in Table in the Appendix A).

Reading the if-then rules from the roots towards the leaves, it can be seen that a number of the discussed factors interact to influence the level of e-business diffusion. It is useful to take into consideration significant rules (which have a satisfactory level of confidence-accuracy and support). Confidence is the number of correctly classified data in a leaf in relation to the total number of data in that leaf, while support is the amount of data in a single leaf in relation to the total amount of data. Thus, for example, the confidence of the rule that corresponds to the leaf - Node 5 is $16 /(16+3+0)$, i.e., about $84 \%$, while the support of this rule is $19 / 152$, that is, about $12 \%$ of all data. Rules whose confidence is over $50 \%$ and support about $10 \%$ can be considered significant.

Table 2 shows the significant if-then rules derived from the model in Figure 2. The derived rules confirm the existence of the interactive effect of the factors on the degree of e-diffusion with satisfactory accuracy. For example, one rule corresponding to Node 12 , with an accuracy of $57 \%$, argues that the low importance of organizational characteristics in interaction with the high significance of IT integration and external support is associated with a higher degree of e-diffusion.

Table 2: Significant rules for the degree of e-business diffusion (for all companies)

\begin{tabular}{|l|l|l|l|}
\hline Node & $\begin{array}{l}\text { Rule } \\
\text { IF }\end{array}$ & THEN & Accuracy(\%) \\
\hline 5 & Low Org.charact & $\begin{array}{l}\text { Low degree of e-business } \\
\text { diffusion }\end{array}$ & 84.2 \\
\hline 7 & High Org.charact and Low IT.integration & $\begin{array}{l}\text { Low degree of e-business } \\
\text { diffusion }\end{array}$ & 68.9 \\
\hline 9 & $\begin{array}{l}\text { High Org.charact and High IT.integration and } \\
\text { Low Ext.support }\end{array}$ & $\begin{array}{l}\text { Low degree of e-business } \\
\text { diffusion }\end{array}$ & 51.7 \\
\hline 13 & $\begin{array}{l}\text { High Org.charact and Low IT.integration and } \\
\text { High Ext.support }\end{array}$ & $\begin{array}{l}\text { Low degree of e-business } \\
\text { diffusion }\end{array}$ & 62.5 \\
\hline 14 & $\begin{array}{l}\text { High Org.charact and High IT.integration and } \\
\text { High Ext.support }\end{array}$ & $\begin{array}{l}\text { High degree of e-business } \\
\text { diffusion }\end{array}$ & 52.3 \\
\hline 12 & $\begin{array}{l}\text { Low Org.charact and High IT.integration and } \\
\text { High Ext.support }\end{array}$ & $\begin{array}{l}\text { High degree of e-business } \\
\text { diffusion }\end{array}$ & 57.1 \\
\hline
\end{tabular}

When generating the model, the individual factors' importance in relation to e-business diffusion is also calculated. Table 3 shows each factor's importance for the degree of e-business diffusion. Those factors for which importance is not displayed do not affect the level of e-business diffusion. 


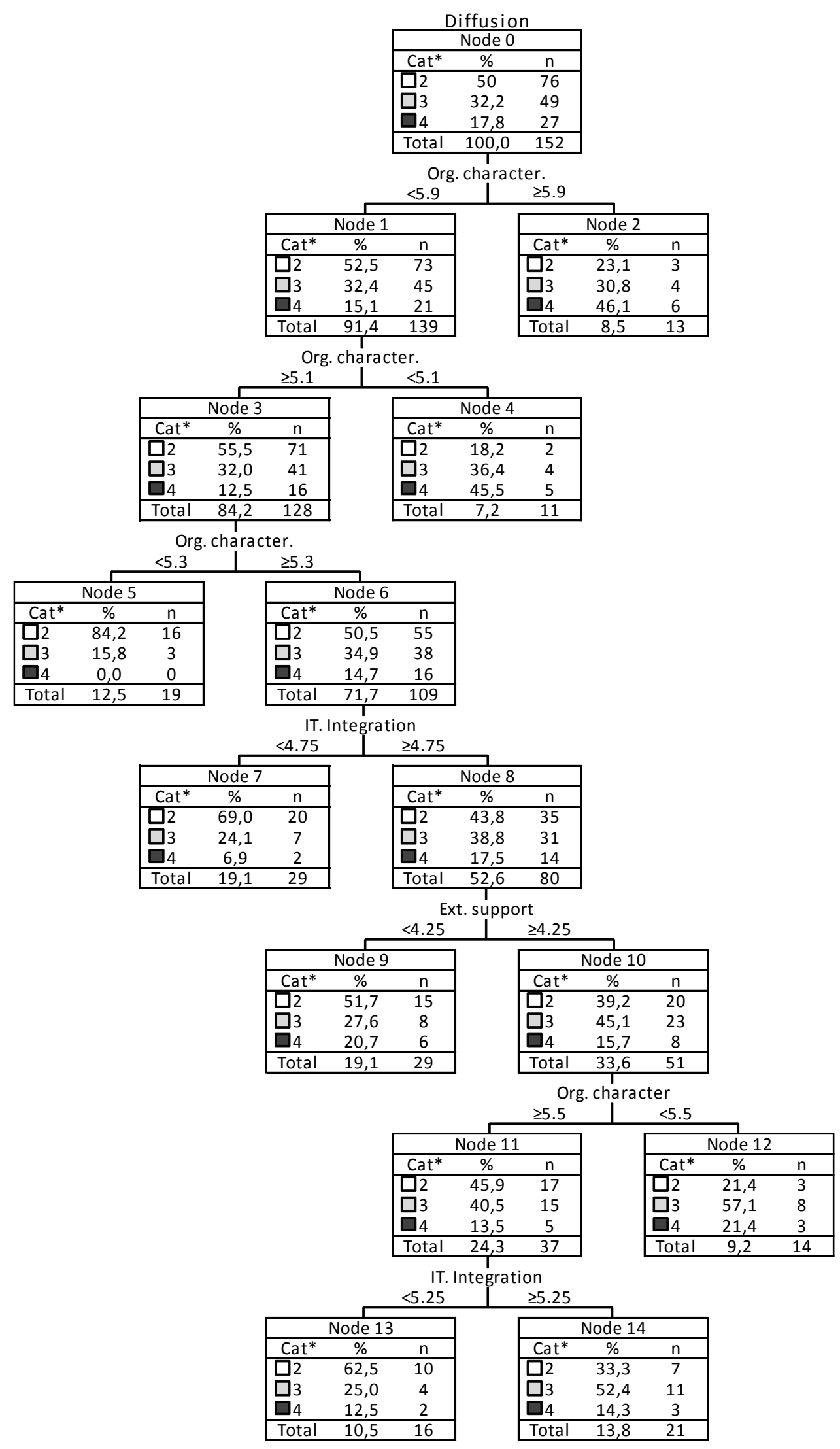

Figure 2: A DT model for the degree of e- business diffusion

Note: ${ }^{*}$ Cat - Category: 2 - Low degree of e - business diffusion, 3 - Middle degree of e - business diffusion, 4 - High degree of e business diffusion (levels 1, 5, 6 and 7 of e-business diffusion are not taken into account due to the small number of data that match them). 
Table 3: Factors importance

\begin{tabular}{|l|l|}
\hline Factor & Importance \\
\hline IT. infrastruct & 1 \\
\hline IT. integration & 23 \\
\hline IT. expertise & \\
\hline Org. character & 55 \\
\hline Org. readiness & 2 \\
\hline Expectations & 2 \\
\hline Ext. req & 4 \\
\hline Ext. support & 14 \\
\hline Regulation & \\
\hline
\end{tabular}

Note: Rounded values are shown

When the results presented in Table 2 and Table 3 (column 2) are compared, conclusions can be drawn concerning the individual and interactive impacts of the analyzed factors on the degree of e-business diffusion (for the whole sample).

At the whole-sample level, the company's organizational characteristics have the most significant positive impact on e-business diffusion. Since companies from this industry in the specific market mainly belong to SMEs, which are characterized by a high impact of organizational factors on the diffusion of IT innovation [54], this finding was not unexpected. This finding is probably a consequence of the organizational characteristics of tourism companies in Montenegro, which predominantly belong to the category of small and medium-sized enterprises. Although they belong to an information-intensive category, where the use of e-business technologies should not be called into question, decisions on the adoption and the degree of use of IT innovations are made only after thorough cost benefit analyzes. Such decisions are still largely dependent on the awareness of the management of the importance of using e-commerce technology, on the employees's readiness to master the use of these technologies, and also on the financial capabilities of these companies.

This means that, in order to accelerate the diffusion of e-business in tourism enterprises, efforts should be made to build awareness among employees that e-business can contribute to: the substitution of labor and capital, the growth of innovation and the development of new products, cost reduction, and consequently a reduction in the price of services, the quality and speed of decision making, the elimination of geographical barriers, accelerating the sales cycle of services and so on. This would help reduce resilience to change and motivate both employees and management to learn more in terms of a higher level of utilization of the concept of e-business in tourism. It could also bring about changes in the mission and vision of these companies. On the other hand, it would lead to an improvement in working conditions, and, thus, indirectly influence the increase in productivity.

The fact that technical factors have not been identified as having the most significant individual impact might have a range of causes. It is possible that employees in tourism companies perceive the degree of technical readiness unrealistically, that is as being much higher than it actually is, but it is also possible that they realize that the potential for technical readiness is irrelevant if there is no organizational readiness. It is also possible that the respondents are aware that their companies are in the initial post-adoption phases and that there is adequate IT readiness for their current activities, which may be the factor with the most significant individual impact only in some later phases, when the system moves toward increasingly routine use.

In addition, the fact that environmental factors did not prove to be the group of factors with the strongest individual impact on the degree of e-business diffusion is due to the fact that in tourism companies, such as those in Montenegro, decisions regarding the expansion of IT innovations are made by a small number of individuals, irrespective of the recommendations and initiatives of professionals and professional associations, external support or regulatory conditions. It is possible that these factors have the greatest individual impact in the e-business adoption phase and that their impact is weakened at each subsequent stage on the way to a routine use of the system. This finding is also consistent with the results of previous studies [18], [43] and shows that it is not unusual for companies in developing countries that the direct or indirect impact of government and other institutions is expected to create a favorable environment to encourage e-business.

However, thanks to the recognized interactive effect, we can see that if the situation in a company is not favourable in terms of achieving a greater degree of e-business diffusion in tourism companies, the problem can be solved by influencing various other factors. In particular, the analysis showed that the problem with organizational characteristics can be overcome if there is a higher degree of IT integration and a high degree of external support (Table 2). 
In terms of significance, organizational characteristics are followed by the factor of IT integration. It is logical that the application of the concept of e-business in tourism implies a high degree of internal and external integration of the existing applications and Internet platforms. The finding that IT integration is of great significance while IT infrastructure is of negligible importance for e-business diffusion in the surveyed enterprises can be explained in two ways. Firstly, this once again confirms that once the decision is made to accept the concept of e-business, the focus inevitably shifts from IT technology acquisition to IT integration [13] and secondly, this finding reflects the state in the country where the problem is not always a lack of IT infrastructure, but the degree and purpose of its use.

Taking into account the results on the interactive effect (Table 2), it can be seen that a low level of IT integration (regardless of the existing positive impact of organizational characteristics, and even of external support) cannot lead to a higher degree of e-business diffusion in Montenegrin tourism companies. Consequently, our analysis has once again confirmed that a more successful and deeper use of a system is achieved only when common technologies become "strategic necessities" [55], [87]. For this reason, the obtained results suggest to the management of companies and the tourism sector generally that there is a need to create policies that will influence the acceleration of the process of IT integration and the transformation of common technologies into capabilities.

The third factor in terms of the importance of its individual impact on e-business diffusion is external support. This finding is also consistent with the results of previous studies [18], [43] and shows that it is not unusual for companies in developing countries that the direct or indirect impact of the government and other institutions is expected to create a favourable environment to encourage e-business.

When considering the interactive impact (Table 2), it can be seen that despite the high positive impact of organizational characteristics and even a high degree of IT integration, at least a minimum degree of external support is needed to achieve a higher degree of e-business diffusion. This finding suggests that in companies from the tourism sector, external support should serve as a potential driver for a more successful presentation in the electronic market through: the use of government programmes to promote and offer tourist services that are based on web and mobile applications; the use of programmes that encourage the creation of new jobs in ICT; financing of participation in international bodies so as to become acquainted with good international practice; strengthening of entrepreneurial culture and the exchange of IT experience in providing services in the field of tourism; the development of new e-business models to fit the tourism services on offer; the use of government support for education in the field of ICT (including practical study training, cooperation between the public and private sectors in order to ensure mobility in the field of IT expertise, and so on); the use of the positive legal, political, institutional and investment climate for cooperation with other tourism companies with experience in this form of business (especially those outside the national framework) and penetration into new markets and so on.

In order to answer the second research question, the decision tree models in Figures 3 and 4 were generated. The overall accuracy of the classification for these models is $62.38 \%$ and $58.82 \%$, respectively (Tables in the Appendix A).

Table 4 and Table 5 summarize the significant rules derived from the generated models.

Table 4: Significant rules for the degree of e-business diffusion (B2C companies)

\begin{tabular}{|l|l|l|l|}
\hline Node & $\begin{array}{l}\text { Rule } \\
\text { IF }\end{array}$ & THEN & Accuracy(\%) \\
\hline 7 & Low Org.character and Low Org.readines & $\begin{array}{l}\text { Low degree of e-business } \\
\text { diffusion }\end{array}$ & 70.3 \\
\hline 9 & High Org.character and Low IT.Expertise & $\begin{array}{l}\text { Low degree of e-business } \\
\text { diffusion }\end{array}$ & 61.5 \\
\hline 10 & High Org.character and High IT.Expertise & $\begin{array}{l}\text { High degree of e-business } \\
\text { diffusion }\end{array}$ & 57.9 \\
\hline
\end{tabular}

Table 5: Significant rules for the degree of e-business diffusion (B2B companies)

\begin{tabular}{|l|l|l|l|}
\hline Node & $\begin{array}{l}\text { Rule } \\
\text { IF }\end{array}$ & THEN & Accuracy(\%) \\
\hline 3 & High Expectations and Low IT.integration & $\begin{array}{l}\text { Low degree of e-business } \\
\text { diffusion }\end{array}$ & $75 \%$ \\
\hline 5 & $\begin{array}{l}\text { High Expectations and High IT.integration and Low } \\
\text { Org.character }\end{array}$ & $\begin{array}{l}\text { Low degree of e-business } \\
\text { diffusion }\end{array}$ & $71.4 \%$ \\
\hline 6 & $\begin{array}{l}\text { High Expectations and High IT.integration and High } \\
\text { Org.character }\end{array}$ & $\begin{array}{l}\text { High degree of e-business } \\
\text { diffusion }\end{array}$ & $62.5 \%$ \\
\hline
\end{tabular}

When generating the models, the individual factors' importance in relation to e-business diffusion is also calculated and presented in Table 6. 


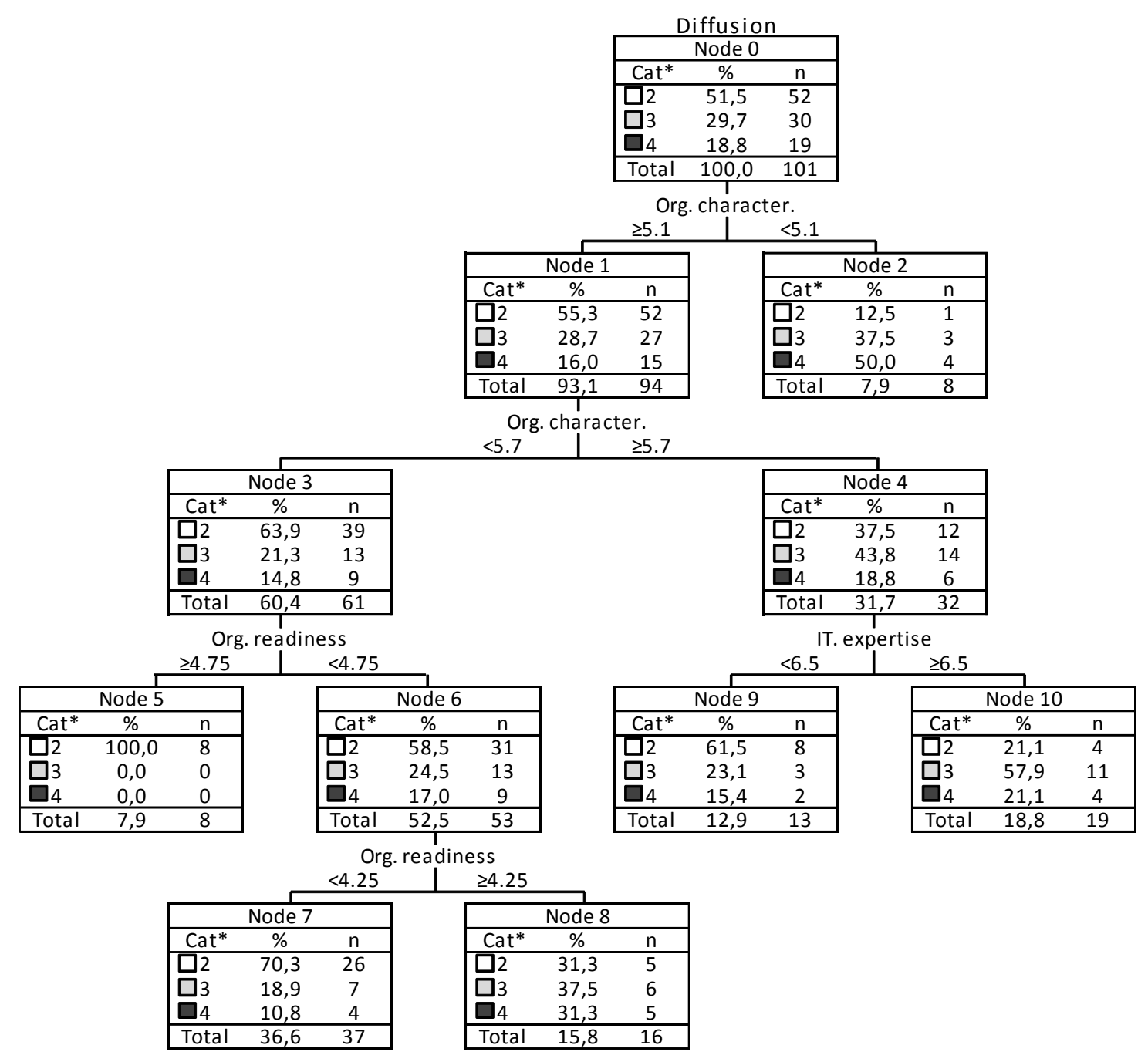

Figure 3: A DT model for the degree of e- business diffusion - B2C businesses

Note: *Cat - Category: 2 - Low degree of e - business diffusion, 3 - Middle degree of e - business diffusion, 4 - High degree of e business diffusion (levels 1, 5, 6 and 7 of e-business diffusion are not taken into account due to the small number of data that match them) 




Figure 4: A DT model for the degree of e- business diffusion - B2B business

Note: *Cat - Category: 2 - Low degree of e - business diffusion, 3 - Middle degree of e - business diffusion, 4 - High degree of e business diffusion (levels 1, 5, 6 and 7 of e-business diffusion are not taken into account due to the small number of data that match them)

Table 6: Factors importance for B2C and B2B

\begin{tabular}{|l|l|l|}
\hline Factor/ Importance & B2C & B2B \\
\hline IT. infrastruct & & \\
\hline IT. integration & 5 & 25 \\
\hline IT. expertise & 17 & \\
\hline Org. character & 37 & 40 \\
\hline Org. readiness & 34 & \\
\hline Expectations & & 32 \\
\hline Ext. req & 1 & \\
\hline Ext. support & 7 & 4 \\
\hline Regulation & & \\
\hline
\end{tabular}

Note: Rounded values are shown

The obtained results show that there are differences in both the individual and interactive impacts of the analyzed factors, depending on whether a company is B2C or B2B. In relation to this, the authors would like to point out several observations.

If we first look at the individual impact of technical factors, we will notice that in B2B companies, IT integration has the greatest individual impact on e-business diffusion, whereas in B2C companies the largest individual impact is exerted by IT expertise. This finding was expected because, unlike their B2C counterparts, B2B companies generally adopt new technologies faster and more easily and aspire to faster IT integration to a greater degree, because working with business partners implies a higher level of compatibility, codification and standardization of procedures [87]. 
In B2C companies, IT expertise is the most influential individual factor, which might lead to the conclusion that companies implementing this concept have not yet entered the more mature stages of e-business diffusion. This means that what these companies currently need is an increase in the attractiveness of their offer to IT profession by increasing motivation in terms of better salaries, training, qualifications, awards and so on. The obtained results are consistent with the results of previous studies [55], [87] and confirm the conclusion that these companies lag behind in the implementation of the e-business concept and that the importance of this factor will decrease only when companies enter the more mature phases of the implementation of e-business, when, logically, IT integration will be of greater influence.

When organizational factors are observed, it can be seen that in $\mathrm{B} 2 \mathrm{C}$ companies, staff and management readiness has a major influence (in contrast to its negligible impact in B2B companies), while in B2B companies, expected benefits exert a strong influence (which is not the case with $\mathrm{B} 2 \mathrm{C}$ companies).

Organizational readiness has so far proved to be a significant determinant for the adoption and diffusion of IT innovation in SMEs [35], [76], and, therefore, the results obtained are by no means surprising, especially due to the fact that the largest number of the surveyed B2C companies are SMEs. Since there is evidence in the scholarly literature that the perception of benefits provides an incentive for the rapid diffusion of technologies that have already been accepted [48], the authors found it surprising that for B2C companies, unlike their B2B counterparts, expected benefits did not have either a strong individual, or a strong combined impact. The authors offer two explanations as to why it is so. First, it is possible that managers and employees in this category of enterprises are still not fully aware of the potential benefits of this way of business operation, and second, it might also be possible that only the initial decisions on adopting certain technologies are made based on the expected benefits from the use of these technologies. Decisions on future, that is, on post-adoption activities, should still, although to a lesser extent, be made on the basis of the expected benefits [29], [48].

The fact that external support is a factor with a greater impact for $\mathrm{B} 2 \mathrm{C}$ companies, with the findings of previous studies taken into account [65], [80], leads to the conclusion that companies in the observed group have lower financial capabilities and a higher degree of dependence on external incentives.

If we observe the interactive impact of the analyzed factors in $\mathrm{B} 2 \mathrm{C}$ companies, we can see that a greater degree of e-business diffusion can occur as a result of greater investment in IT expertise and a greater degree of organizational adjustments. For B2B companies, a higher level of e-business diffusion could result from the interactive impact of the expected benefits, the organizational characteristics of an enterprise and IT integration.

The obtained results show that the CART method provides good overall accuracy (with a model precision value of about $60 \%$ ), and that CART analysis is an appropriate method for analyzing e-business diffusion determinants.

\section{Conclusion}

This study has shown to what extent technical, organizational and environmental factors affect the level of ebusiness diffusion in tourism enterprises.

It shows that in addition to individual elements, it is possible to also identify the interactive impact of the analyzed factors. In addition, it was shown that there is a difference between the individual and interactive impact depending on whether companies implement the B2B or B2C concept.

Analysis was carried out for all the surveyed enterprises in the tourism sector and it showed that organizational factors had the highest individual impact. This result leads to several conclusions: the observed enterprises are still not mature enough in organizational terms to have a higher degree of e-business diffusion; for these companies, there is still work to be done on strengthening human resources and management capabilities, changing the attitude of management regarding the further use of e-business platforms, insisting on increasing their financial support and other forms of encouragement; and so on. Furthermore, according to the findings of the present study, we can conclude that the observed companies did not find adequate solutions as regards organizational issues around IT competencies, the allocation of funds for these purposes, the organization of tasks for IT support and other areas. In addition, it is obvious that in the analyzed companies, there is still a lot to be done related to campaigns that will heighten awareness of the economic and social benefits of e-business.

Both groups of companies have the necessary IT infrastructure, but it is recognized that in B2C companies further efforts should be made to strengthen IT expertise, whereas in B2B companies, IT integration should be strengthened. In order words, the management of B2B companies should focus their future activities on accelerating IT integration, while the management of B2C enterprises should allocate additional resources to the IT training of staff and use the services of university units, local or international sources of IT expertise and other relevant stakeholders.

External support is recognized as a factor that encourages companies to accept and begin to use new technological solutions and can be understood as a driving force for the adoption of e-business, but it is not good that the impact of this factor among companies in the field of tourism is also evident in e-business diffusion. Managers (especially 
those working for $\mathrm{B} 2 \mathrm{C}$ companies) should interpret this as a sign of alarm. To be more specific, too much reliance on external stimuli and the practices or experience of others in the use of a system is not helpful and can be replaced by influencing another group of technical or organizational factors. However, this is only possible if there is information on the interactive impact factors.

Studying the interactive impact of the analyzed factors for enterprises in the tourism sector shows the strong interactive influence of three groups of factors: IT integration, organizational characteristics and external support. In terms of the interactive impact of the analyzed factors in $\mathrm{B} 2 \mathrm{C}$ companies, the authors concluded that a higher degree of e-business diffusion can be achieved by simultaneously investing in IT expertise and organizational readiness. On the other hand, in B2B companies simultaneous efforts should be made towards greater IT integration and greater organizational readiness as well as towards raising awareness of the benefits of e-business.

Thanks to the recognized interaction of factors, managers of companies which should encourage e-business diffusion can reduce the importance of the impact of one group of factors by influencing another group of factors.

This study offers theoretical, methodological and practical implications. In terms of theory, this study expands the body of empirical research on e-business diffusion and amends the existing literature in that that in this context it studies the individual and interactive impacts of the analyzed factors using the TOE framework and the DT method. The idea of testing the combined impact of factors can thus aid other researchers in their future research. In addition, it can be an incentive for other researchers to address issues that will accelerate e-business diffusion in other less developed economies, or serve as a basis for the comparative analyses of results obtained in countries with different levels of socio-economic development.

From a methodological point of view, the study showed that the DT method is a good alternative to the standard twostage regression procedures for detecting factors that affect e-business diffusion. The advantage of this method is in its immediate detection of the importance of factors and the relationship between the factors and dependent variables without the need to anticipate these relationships in advance in a hypothetical structural model. In this way, we avoid the possibility of overlooking certain important relationships.

In terms of practical implications, the authors believe that thanks to the results of this study, managers and policy makers may consider ICT opportunities and barriers to ICT diffusion and adoption in the domain of e-business diffusion in tourism. The obtained results can serve as guidelines when deciding on investment in IT staffing and integration, when making decisions regarding the allocation and allocation dynamics of human and financial resources, and in various other areas. Thanks to the examined interactive impact of the factors, managers can make fine adjustments in terms of their impact on a group of factors, if the situation with regard to another group of factors is not favourable. Managers can use this information to promote the concept to employees, other stakeholders and the general public. On the other hand, for ICT policy makers, this study suggests that their support programmes, and the legal and institutional framework are not important only in the initiation and approval stages, but also later in the process of the diffusion of the innovation.

This study has several limitations, which might provide opportunities for future research. Firstly, the study was conducted for a country that has a lower level of socio-economic and technical development. The authors' idea was to draw certain conclusions on e-business diffusion in the context of developing countries, such as Montenegro, all the more so taking into account the fact that the focus of most studies conducted so far was on developed market economies. The authors believe that it would be interesting to conduct a study for a larger number of countries and to identify the differences between developed and developing countries. Secondly, the companies where the research was done were mainly small and medium-sized enterprises which had only just passed through the period of the adoption of e-business. Since about $2 \%$ of Montenegrin enterprises belong to the category of large companies, and the remainder (almost 98\%) to that of SMEs, the authors are aware that the results of this study can only be used for analysis in the context of SMEs and that they cannot be used to make any generalized conclusions for all categories of enterprises. Thirdly, this study could be expanded through the analysis of the impact of technical, organizational and environmental factors at different stages of e-business assimilation (from initiation to routinization) but not before Montenegro tourism reaches the more mature stages of the use of e-business platforms and the employees of tourism companies understand the differences between the various stages of assimilation. Fourthly, the authors are aware that the focus might be shifted from a single industry towards a comparison of findings for a larger number of economic activities, or indeed all of them. However, the intentions of this study were to observe the importance of the individual and interactive impact of the selected determinants of e-business diffusion in the context of enterprises from a precisely defined industry - tourism. This was particularly so because Montenegro is a country with great tourism potential.

Next, since in other studies on IT innovation, the choice of theoretical frameworks and attribute selection was not perceived as set in stone, and again due to the specificity of e-business as an IT innovation, the authors have modified the original TOE framework, especially as regards organizational factors, and they believe that in future research it would be useful to observe the impact of other factors on e-business diffusion.

Finally, a dynamic approach to the study of this problem through the various stages of the assimilation process, for a certain number of years, along with a set of data that would enable us to see the functional possibilities of e-business, 
would provide a research basis to determine the causal relationships between the examined impacts. This should be possible when companies from Montenegro come closer to companies from developed market economies in terms of adopting and using e-business technologies. Then, over time, the authors might be able to improve the research design and the database.

\section{References}

[1] M. G. Aboelmaged, Predicting e-readiness at firm-level: an analysis of technological, organizational and environmental (TOE) effects on e-maintenance readiness in manufacturing firms, International Journal of Information Management, vol. 34, no.5, pp. 639-651, 2014.

[2] M. Abou-Shouk, W. M. Lim and P. Megicks, Internet adoption by travel agents: A case of Egypt, International Journal of Tourism Research, vol. 15, no. 3, pp. 298-312, 2013.

[3] A. Acker, The short message service: Standards, infrastructure and innovation, Telematics and informatics, vol. 31, no. 4, pp. 559-568, 2014.

[4] V. Ali, Factor affecting the adoption of information and communication technology in the tourism sector of the Maldives, M.S. thesis, Victoria University of Wellington, Wellington, New Zealand, 2014.

[5] M. Banyai and M.E. Havitz, Analyzing travel blogs using a realist evaluation approach, Journal of Hospitality Marketing and Management, vol. 22, no. 2, pp. 229-241, 2013

[6] A. Bethapudi, The role of ICT in tourism industry, Journal of Applied Economics and Business, vol. 1, no. 4, pp. 67-79, 2013.

[7] G. Bhandari, Adoption and diffusion of ICT in real estate industry: An empirical study, In ASAC, vol. 30, no. 25, 2009.

[8] V. Bordonaba-Juste, L. Lucia-Palacios and Y. Polo-Redondo, Antecedents and consequences of e-business adoption for European retailers, Internet Research, vol. 22, no. 5, pp. 532-550, 2012

[9] L. Breiman, J. Friedman, C. J. Stone, and R.A. Olshen, Classification and Regression Trees. Boca Raton: CRC press, 1984.

[10] D. H. Brown and L. Kaewkitipong, Relative size and complexity: e-business use in small and medium sized tourism enterprises in Thailand, Journal of Enterprise Information Management, vol. 22, no.1/2, pp. 212-231, 2009

[11] D. Buhalis and R. Law, Progress in information technology and tourism management: 20 years on and 10 years after the Internet - The state of e-tourism research, Tourism Management, vol. 29, no. 4, pp. 609- 623, 2008.

[12] Q. Cao, J. Baker, J.C. Wetherbe, and V. C. Gu. (2012, June) Organizational adoption of innovation: Identifying factors that influence RFID adoption in the healthcare industry. AIS Electronic Library (AISeL). [Online]. Available: http://aisel.aisnet.org/ecis2012/94.

[13] F. T. Chan and A. Y. L. Chong, Determinants of mobile supply chain management system diffusion: a structural equation analysis of manufacturing firms, International Journal of Production Research, vol. 51, no. 4, pp. 1196$1213,2013$.

[14] D. Chatterjee, R. Grewal and V. Sambamurthy, Shaping up for e-commerce: Institutional enablers of the organizational assimilation of Web technologies, MIS Quart. vol. 26, no. 2, pp. 65-89, 2002

[15] A. Y. L. Chong and F. T. Chan, Structural equation modeling for multi-stage analysis on radio frequency identification (RFID) diffusion in the health care industry, Expert Systems with Applications, vol. 39, no. 10, pp. 8645-8654, 2012.

[16] S. Cho, L. Mathiassen and M. Gallivan, Crossing the chasm: From adoption to diffusion of a telehealth innovation. In IFIP Working Conference on Open IT-Based Innovation: Moving Towards Cooperative IT Transfer and Knowledge Diffusion. Boston, MA: Springer, Boston, 2008.

[17] M. C. Chou, Does tourism development promote economic growth in transition countries? A panel data analysis, Economic Modelling, vol. 33, pp. 226-232, 2013.

[18] P. Datta, A preliminary study of ecommerce adoption in developing countries, Information Systems Journal, vol. 21, no. 1, pp. 3-32, 2011

[19] J. de Oña, R. de Oña and F.J. Calvo, A classification tree approach to identify key factors of transit service quality, Expert Systems with Applications, vol. 39, no. 12, pp. 11164-11171, 2012.

[20] R. Depietro, E. Wiarda and M. Fleischer, The context for change: Organization, technology and environment, The Processes of Technological Innovation, vol. 199, pp. 151-175, 1990.

[21] V. K. Durbhakula and D. J. Kim, E-business for nations: A study of national level ebusiness adoption factors using country characteristics-business-technology-government framework, Journal of Theoretical and Applied Electronic Commerce Research, vol. 6, no. 3, pp. 1-12, 2011.

[22] T. Escobar-Rodriguez and E. Carvajal-Trujillo, An evaluation of Spanish hotel websites: Informational vs. relational strategies, International Journal of Hospitality Management, vol. 33, no. 1, pp. 228-239, 2013

[23] European Commission. (2010, June) Communication from the Commission to the European Parliament, the Council, the European Economic and Social Committee and the Committee of the Regions. Europe, the world's no 1 tourist destination - a new political framework for tourism in Europe. European Commission. [Online]. Available: https://eur-lex.europa.eu/legal-content/EN/TXT/PDF/?uri=CELEX:52010DC0352\&from=EN

[24] J.I.P. Fernández, A. Sáez Cala and C.F. Domecq, Critical external factors behind hotels' investments in innovation and technology in emerging urban destinations, Tourism Economics, vol. 17, no. 2, pp. 339-357, 2011. 
[25] R.G. Fichman, The Diffusion and Assimilation of Information Technology Innovations. Framing the Domains of IT Management: Projecting the Future Through the Past. Cincinnati, OH: Pinnaflex Educational Resources, Inc. 2000.

[26] M. Fuchs, W. Höpken, A. Föger, and M. Kunz, E-business readiness, intensity, and impact: An Austrian destination management organization study, Journal of Travel Research, vol. 49, no. 2, pp. 165-178, 2010.

[27] M. Fuchs, C. Witting and W. Höpken, E-business readiness, intensity and impact-An Austrian hotel study, Information and Communication Technologies in Tourism 2009, pp. 431-442, 2009.

[28] H. Gatignon and T.S. Robertson, Technology diffusion: an empirical test of competitive effects, The Journal of Marketing, vol. 53, no. 1, pp. 35-49, 1989.

[29] M. Ghobakhloo, D. Arias-Aranda and J. Benitez-Amado, Adoption of e-commerce applications in SMEs, Industrial Management \& Data Systems, vol.111, no. 8, pp. 1238-1269, 2011

[30] D. L. Goodhue and R.L. Thompson, Task-technology fit and individual performance, MIS quarterly, vol. 19 , no. 2, pp. 213-236, 1995.

[31] S.A. Haller and I. Siedschlag, Determinants of ICT adoption: Evidence from firm-level data, Applied Economics, vol. 43, no. 26 , pp. 3775-3788, 2011.

[32] B. C. Hardgrave, D.J. Armstrong and C.K. Riemenschneider, RFID assimilation hierarchy, in Proceedgins System Sciences, 2007, HICSS 2007, 40th Annual Hawaii International Conference on, Big Island, Hawaii, Jan. 3, 2007 to Jan. 6, 2007, pp. 224b-224b.

[33] B. Hillebrand, J.J. Nijholt and E.J. Nijssen, Exploring CRM effectiveness: an institutional theory perspective, Journal of the Academy of Marketing Science, vol. 39, no. 4, pp. 592-608, 2011.

[34] M. Holzner, Tourism and economic development: The beach disease?, Tourism Management, vol. 32, no. 4, pp. 922-933, 2011

[35] P.F. Hsu, K.L. Kraemer and D. Dunkle, Determinants of e-business use in US firms, International Journal of Electronic Commerce, vol 10, no. 4, pp. 9-45, 2006.

[36] S.M. Huang, C.S. Ou, C.M. Chen, and B. Lin, An empirical study of relationship between IT investment and firm performance: A resource-based perspective, European Journal of Operational Research, vol. 173, no. 3, pp. 984-999, 2006

[37] P. Ifinedo, Internet/e-business technologies acceptance in Canada's SMEs: an exploratory investigation, Internet Research, vol. 21, no. 3, pp. 255-281, 2011

[38] A. Jeyaraj, J.W. Rottman and M.C. Lacity, A review of the predictors, linkages, and biases in IT innovation adoption research, Journal of Information Technology, vol. 21, no. 1, pp. 1-23, 2006.

[39] E. Ko, S.H. Kim, M. Kim, and J.Y. Woo, Organizational characteristics and the CRM adoption process, Journal of Business Research, vol. 61, no. 1, pp. 65-74, 2008.

[40] T.H. Kwon and R.W. Zmud, Unifying the fragmented models of information systems implementation, in Critical Issues in Information Systems Research (R. J. Boland, Jr. and R. A. Hirschheim, Eds.). New York: John Wiley \& Sons, Inc., 1987, pp. 227-251.

[41] R. Law, D. Buhalis and C. Cobanoglu, Progress on information and communication technologies in hospitality and tourism, International Journal of Contemporary Hospitality Management, vol. 26, no. 5, pp: 727-750, 2014.

[42] R. Law, R. Leung and D. Buhalis, Information technology applications in hospitality and tourism: A review of publications from 2005 to 2007, Journal of Travel \& Tourism Marketing, vol. 26, no. 5, pp. 599-623, 2009

[43] J.E. Lawrence and U.A. Tar, Barriers to e-commerce in developing countries, Information, Society and Justice Journal, vol. 3, no. 1, pp. 23-35, 2010.

[44] H. Lee and R. Law, Diversity in statistical research techniques: An analysis of refereed research articles in the Journal of Travel \& Tourism Marketing, vol. 29, no. 1, pp. 1-17, 2012

[45] H.S. Lee and S. Whang, Winning the last mile of e-commerce, Sloan Management Review vol. 42, no. 4, pp. 54-63, 2001.

[46] J. Li, Y.F. Wang, Z.M. Zhang and C.H. Chu, Investigating acceptance of RFID in Chinese firms: The technology-organization-environment framework, in Proceedgins RFID-Technology and Applications (RFID-TA) 2010 IEEE International Conference on, Guangzhou, China, pp. 263-268, 2010.

[47] H.F. Lin, The effects of knowledge management capabilities and partnership attributes on the stage-based ebusiness diffusion, Internet Research, vol. 23, no. 4, pp. 439-464, 2013.

[48] H.F. Lin and S.M. Lin, Determinants of e-business diffusion: A test of the technology diffusion perspective, Technovation, vol. 28, no. 3, pp. 135-145, 2008

[49] H.F. Lin and G.G. Lee, Impact of organizational learning and knowledge management factors on e-business adoption, Management Decision, vol. 43, no. 2, pp. 171-188, 2005.

[50] H.F. Lin, G.G. Lee and C.P. Lee, The influence of partnership attributes on the perceived benefits of businessto-business electronic commerce, Asia Pacific Management Review, vol. 10, no. 5, pp. 329-339, 2005

[51] S.W. Lin and H.P. Fu, Uncovering critical success factors for business-to-customer electronic commerce in travel agencies, Journal of Travel \& Tourism Marketing, vol. 29, no. 6, pp. 566-584, 2012.

[52] C. Low, Y. Chen and M. Wu, Understanding the determinants of cloud computing adoption, Industrial Management \& Data Systems, vol. 111, no. 7, pp. 1006-1023, 2011

[53] L. Lucia-Palacios, V. Bordonaba-Juste, Y. Polo-Redondo and M. Grünhagen, E-business implementation and performance: analysis of mediating factors, Internet Research, vol. 24, no. 2, pp. 223-245, 2014

[54] Y.H.V. Lun and M.A. Quaddus, Firm size and performance: A study on the use of electronic commerce by container transport operators in Hong Kong, Expert System Application, vol. 38, pp. 7227-7234, 2011

[55] R. Martins, T. Oliveira and M.A. Thomas, An empirical analysis to assess the determinants of SaaS diffusion in firms, Computers in Human Behavior, vol. 62, pp. 19-33, 2016. 
[56] A.D. Meyer and J.B. Goes, Organizational assimilation of innovations: a multilevel contextual analysis, Academy of Management Journal, vol. 31, no. 4, pp. 897-923, 1988.

[57] W. Mun Lim, Alternative models framing UK independent hoteliers' adoption of technology, International Journal of Contemporary Hospitality Management, vol. 21, no. 5, pp. 610-618, 2009.

[58] H.C. Murphy and C.D. Kielgast, Do small and medium-sized hotels exploit search engine marketing?, International Journal of Contemporary Hospitality Management, vol. 20, no. 1, pp. 90-97, 2008

[59] H.O. Nguyen, Critical factors in e-business adoption: Evidence from Australian transport and logistics companies, International Journal of Production Economics, vol. 146, no. 1, pp. 300-312, 2013

[60] T. Oliveira and M.F. Martins, Understanding e-business adoption across industries in European countries, Industrial Management \& Data Systems, vol. 110, no. 9, pp. 1337-1354, 2010.

[61] T. Oliveira and M.F. Martins, Literature review of information technology adoption models at firm level, The Electronic Journal Information Systems Evaluation, vol. 14, no. 1, pp. 110-121, 2011

[62] D. Palacios-Marqués, P. Soto-Acosta and J.M. Merigó, Analyzing the effects of technological, organizational and competition factors on Web knowledge exchange in SMEs, Telematics and Informatics, vol. 32, no. 1, pp. 23-32, 2015.

[63] J. Pansiri and Z.T. Temtime, Linking firm and managers' characteristics to perceived critical success factors for innovative entrepreneurial support, Journal of Small Business and Enterprise Development, vol. 17, no. 1, pp. 45-59, 2010.

[64] A.I.P. Peña, D.M.F. Jamilena and M. Á. R. Molina, Validation of a market orientation adoption scale in rural tourism enterprises. Relationship between the characteristics of the enterprise and extent of market orientation adoption, International Journal of Hospitality Management, vol. 31, no. 1, pp. 139-151, 2012.

[65] A. Pucihar and M. Podlogar, E-marketplace adoption success factors: Challenges and opportunities for a small developing country, Electronic Business in Developing Countries: Opportunities and Challenges. Hershey: Idea Group, 2006

[66] V. Pujani, Y.H. Yeni, E. Widiastuty, and T. Asmony, A study toward website adoption level among travel agencies in Indonesia using technology-organization-environment model, Advanced Science Letters, vol. 23, no. 1, pp. 490-493, 2017

[67] J.R. Quinlan, C4. 5: Programs for Machine Learning (Vol. 1). San Mateo, CA: Morgan Kaufmann, 1993.

[68] P. Rajagopal, An innovation-diffusion view of implementation of enterprise resource planning systems and development of a research model, Information and Management, vol. 40, no. 2, pp. 87-114, 2002.

[69] C. Ranganathan, T. Teo and J. Dhaliwal, Web-enabled supply chain management: Key antecedents and performance impacts, International Journal of Information Management, vol. 31, no. 6, pp. 533-545, 2011

[70] L. Raymond, F. Bergeron and S. Blili, The assimilation of E-business in manufacturing SMEs: Determinants and effects on growth and internationalization, Electronic Markets, vol. 15, no. 2, pp. 106-118, 2005

[71] E. Rogers, Diffusion of Innovation. New York: Free Press, 1995

[72] S. Sahadev and N. Islam, Why hotels adopt ICTs: a study on the ICT adoption propensity of hotels in Thailand, International Journal of Contemporary Hospitality, 2005

[73] C.C. Shen and J.S. Chiou, The impact of perceived ease of use on Internet service adoption: The moderating effects of temporal distance and perceived risk, Computers in Human Behavior, vol. 26, no. 1, pp. 42-50, 2010.

[74] W. Shi, N. Shambare and J. Wang, The adoption of internet banking: An institutional theory perspective, Journal of Financial Services Marketing, vol. 12, no.4, pp. 272-286, 2008

[75] A. Siguaw, A. Enz and K. Namasivayam, Adoption of information technology in US hotels: Strategically driven objectives, Journal of Travel Research, vol. 39, no. 2, pp. 192-201, 2000

[76] I. Sila, Factors affecting the adoption of B2B e-commerce technologies, Electronic Commerce Research, vol. 13, no. 2, pp. 199-236, 2013.

[77] A. Singh and S. Munjal, Issues and concerns in technology decisions: The hotel operator's perspective, Worldwide Hospitality and Tourism Themes, vol. 4, no. 2, pp. 174-184, 2012

[78] E.B. Swanson and N.C. Ramiller, Innovating mindfully with information technology, MIS quarterly, vol. 28, no. 4, pp. 553-583, 2004.

[79] D.J. Telfer and R. Sharpley, Tourism and Development in the Developing World. London: Routledge, 2015.

[80] T.L. Teo, C. Chan and C. Parker. (2008, August) Factors affecting e-commerce adoption by SMEs: A metaanalysis. AIS Electronic Library (AISeL). [Online]. Available: http://aisel.aisnet.org/acis2004/54

[81] J.Y. Thong and C.S. Yap, CEO characteristics, organizational characteristics and information technology adoption in small businesses, Omega, vol. 23, no. 4, pp. 429-442, 1995.

[82] K. Vicky, The role of ICTs in regional tourist development, Regional Science Inquiry, vol. 3, no. 2, pp. 95-111, 2011.

[83] Z. Vladimirov, Factors for the e-business adoption by small tourism firms and the role of shadow economic practices, European Journal of Tourism Research, vol. 10, no. 5, 2015.

[84] Z. Vladimirov, E-business adoption by small tourism firms and shadow economic practices. In encyclopedia of e-commerce development, implementation, and management, Hershey, Pennsylvania: IGI Global, vol. I, category: E-Commerce Strategies, pp. 563-577, 2016.

[85] Y. Wang and X. Shi, E-business assimilation in SMEs of China, International Journal of Electronic Business, vol. 7 , no. 5, pp. 512-535, 2009

[86] K. Zhu, S. Dong, S.X. Xu, and K.L. Kraemer, Innovation diffusion in global contexts: determinants of postadoption digital transformation of European companies, European Journal of Information Systems, vol. 15, no. 6, pp. 601-616, 2006 
[87] K. Zhu, K. Kraemer and S. Xu, The process of innovation assimilation by firms in different countries: A technology diffusion perspective on e-business, Management Science, vol. 52, no. 10, pp. 1557-1576, 2006b.

[88] K. Zhu, K. L. Kraemer and S. Xu, E-business adoption by European firms: A cross-country assessment of the facilitators and inhibitors, European Journal of Information Systems, vol. 12, no. 4, pp. 251-268, 2003.

[89] K. Zhu and K.L. Kraemer, Post-adoption variations in usage and value of e-business by organizations: Crosscountry evidence from the retail industry, Information systems research, vol. 16, no. 1, pp. 61-84, 2005 


\section{Appendix A: The Accuracy of the Decision Tree Classification Model}

The accuracy of the classification of the degree of e-business diffusion (confusion matrix)

\begin{tabular}{|l|l|l|l|l|}
\hline Pred./True & 2 & 3 & 4 & Class precision \\
\hline 2 & 61 & 22 & 10 & $65.59 \%$ \\
\hline 3 & 10 & 19 & 6 & $54.29 \%$ \\
\hline 4 & 5 & 8 & 11 & $45.83 \%$ \\
\hline Class recall & $80.26 \%$ & $38.78 \%$ & $40.74 \%$ & Accuracy:59.87\% \\
\hline
\end{tabular}

Note: The table represents a confusion matrix. A confusion matrix is a specific table layout that allows the visualization of the performance of a classification model. Each row of the matrix represents the instances in a predicted class, while each column represents the instances in an actual class. Accuracy is thus the relative number of correctly classified examples or in other words the percentage of correct predictions. Class precision is the relative number of correctly classified examples among all the examples classified in a class. Class recall specifies the relative number of correctly classified examples among all the actual examples in a class.

The accuracy of the classification of the degree of e-business diffusion for B2C (confusion matrix)

\begin{tabular}{|l|l|l|l|l|}
\hline Pred./True & 2 & 3 & 4 & \\
\hline 2 & 42 & 10 & 6 & $72.41 \%$ \\
\hline 3 & 9 & 17 & 9 & $48.57 \%$ \\
\hline 4 & 1 & 3 & 4 & $50.00 \%$ \\
\hline Class recall & $80.77 \%$ & $56.67 \%$ & $21.05 \%$ & Accuracy:62.38\% \\
\hline
\end{tabular}

The accuracy of the classification of the degree of e-business diffusion for B2B (confusion matrix)

\begin{tabular}{|l|l|l|l|l|}
\hline Pred./True & 2 & 3 & 4 & \\
\hline 2 & 14 & 4 & 1 & $73.68 \%$ \\
\hline 3 & 5 & 10 & 1 & $62.50 \%$ \\
\hline 4 & 5 & 5 & 6 & $37.50 \%$ \\
\hline Class recall & $58.33 \%$ & $52.63 \%$ & $75.00 \%$ & Accuracy:58.82\% \\
\hline
\end{tabular}




\section{Appendix B: Survey Questions}

\begin{tabular}{|c|c|}
\hline Variables & Items \\
\hline $\begin{array}{l}\text { Existing IT } \\
\text { infrastructure }\end{array}$ & $\begin{array}{l}\text { 1. In our company, the diffusion of e-business is influenced by the quality of the } \\
\text { existing IT infrastructure }\end{array}$ \\
\hline \multirow[t]{2}{*}{ IT integration } & $\begin{array}{l}\text { 1. In our company, the diffusion of e-business is influenced by the compatibility of the } \\
\text { existing IT infrastructure and the IT infrastructure of our subcontractors and clients }\end{array}$ \\
\hline & $\begin{array}{l}\text { 2. In our company, the diffusion of e-business is influenced by the compatibility of the } \\
\text { existing IT infrastructure and the technical solutions for e-business }\end{array}$ \\
\hline IT expertise & 1. In our company, the diffusion of e-business is influenced by our own IT expertise \\
\hline \multirow[t]{5}{*}{$\begin{array}{l}\text { Organisational } \\
\text { characteristics }\end{array}$} & $\begin{array}{l}\text { 1. In our company, the diffusion of e-business depends on the industry that our } \\
\text { company belongs to }\end{array}$ \\
\hline & $\begin{array}{l}\text { 2.In our company, the diffusion of e-business depends on the character of our primary } \\
\text { activity }\end{array}$ \\
\hline & 3.In our company, the diffusion of e-business depends on the age of the company \\
\hline & $\begin{array}{l}\text { 4.In our company, the diffusion of e-business depends on the mission and vision of the } \\
\text { company }\end{array}$ \\
\hline & $\begin{array}{l}\text { 5.In our company, the diffusion of e-business depends on the availability of our own } \\
\text { financial resources for the development and implementation of e-business }\end{array}$ \\
\hline \multirow{2}{*}{$\begin{array}{l}\text { Management } \\
\text { and } \\
\text { organisational } \\
\text { readiness }\end{array}$} & $\begin{array}{l}\text { 1.In our company, the diffusion of e-business depends on management support for } \\
\text { investment in the e-business infrastructure }\end{array}$ \\
\hline & $\begin{array}{l}\text { 2. In our company, the diffusion of e-business depends on the awareness of our } \\
\text { employees as to the importance of e-business. }\end{array}$ \\
\hline \multirow{12}{*}{$\begin{array}{l}\text { Economic and } \\
\text { social } \\
\text { expectations- } \\
\text { benefits }\end{array}$} & $\begin{array}{l}\text { 1.In our company, the diffusion of e-business depends on the expectations regarding } \\
\text { the substitution of labour by ICT }\end{array}$ \\
\hline & $\begin{array}{l}\text { 2. In our company, the diffusion of e-business depends on the expectations regarding } \\
\text { the substitution of capital by ICT }\end{array}$ \\
\hline & $\begin{array}{l}\text { 3.In our company, the diffusion of e-business depends on the expectations regarding } \\
\text { an increased market share }\end{array}$ \\
\hline & $\begin{array}{l}\text { 4. In our company, the diffusion of e-business depends on the expectations regarding } \\
\text { revenue increase }\end{array}$ \\
\hline & $\begin{array}{l}\text { 5. In our company, the diffusion of e-business depends on the expectations regarding } \\
\text { saving. }\end{array}$ \\
\hline & $\begin{array}{l}\text { 6. In our company, the diffusion of e-business depends on the expectations regarding } \\
\text { an increase in the quality of communication with our subcontractors and clients }\end{array}$ \\
\hline & $\begin{array}{l}\text { 7. In our company, the diffusion of e-business depends on the expectations regarding } \\
\text { an increase in the quality of business processes }\end{array}$ \\
\hline & $\begin{array}{l}\text { 8. In our company, the diffusion of e-business depends on the expectations regarding } \\
\text { an increase in the speed of the execution of business processes. }\end{array}$ \\
\hline & $\begin{array}{l}\text { 9.In our company, the diffusion of e-business depends on the expectations regarding } \\
\text { reducing the number of mistakes at work }\end{array}$ \\
\hline & $\begin{array}{l}\text { 10.In our company, the diffusion of e-business depends on the expectations regarding } \\
\text { Customer Service Quality improvement }\end{array}$ \\
\hline & $\begin{array}{l}\text { 11. In our company, the diffusion of e-business depends on the expectations regarding } \\
\text { strengthening the image of our company as innovative. }\end{array}$ \\
\hline & $\begin{array}{l}\text { 12.In our company, the diffusion of e-business depends on the expectations regarding } \\
\text { increasing the quality of decision-making, management and control }\end{array}$ \\
\hline \multirow{3}{*}{$\begin{array}{l}\text { External } \\
\text { demands and } \\
\text { pressures }\end{array}$} & $\begin{array}{l}\text { 1.In our company, the diffusion of e-business depends on the subcontractors' } \\
\text { demands }\end{array}$ \\
\hline & 2.In our company, the diffusion of e-business depends on the clients' demands \\
\hline & $\begin{array}{l}\text { 3.In our company, the diffusion of e-business depends on pressure from our } \\
\text { competition }\end{array}$ \\
\hline \multirow[t]{2}{*}{$\begin{array}{l}\text { External } \\
\text { support }\end{array}$} & $\begin{array}{l}\text { 1.In our company, the diffusion of e-business depends on government support and } \\
\text { measures to encourage the use of ICT }\end{array}$ \\
\hline & $\begin{array}{l}\text { 2.In our company, the diffusion of e-business depends on the support of local financial } \\
\text { institutions }\end{array}$ \\
\hline \multirow{2}{*}{$\begin{array}{l}\text { Regulation } \\
\text { Degree of e- } \\
\text { business } \\
\text { diffusion }\end{array}$} & 1. In our company, the diffusion of e-business depends on legal regulations \\
\hline & 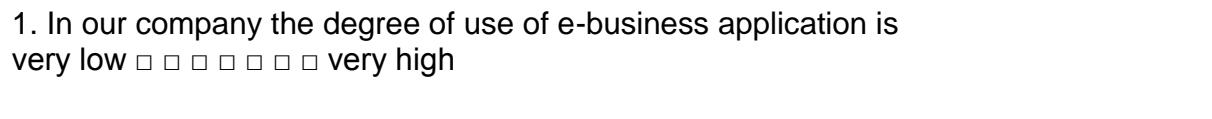 \\
\hline
\end{tabular}

